\title{
Functional Characteristics of the Diluting Segment of the Dog Nephron and the Effect of Extracellular Volume Expansion on Its Reabsorptive Capacity*
}

\author{
Garabed Eknoyan, Wadi N. Suki, Floyd C. Rector, Jr., and \\ Donald W. Seldin $\dagger$ \\ (From the Department of Internal Medicine, The University of Texas Southwestern Medical \\ School, Dallas, Texas)
}

Summary. The functional characteristics of the ascending limb of Henle's loop were examined during hypotonic saline infusion by measuring solutefree water clearance $\left(\mathrm{C}_{\mathrm{H}_{2} \mathrm{O}}\right)$ at varying rates of solute delivery. The influence of expansion of extracellular volume was studied by comparing $\mathbf{C}_{\mathrm{H}_{2} \mathrm{O}}$ during hypotonic saline diuresis in normal dogs with dogs whose extracellular volume had been expanded acutely by saline infusions or chronically by the administration of deoxycorticosterone acetate and salt.

In normal animals hypotonic saline infusions greatly increased urine flow (V) and $\mathrm{C}_{\mathrm{H}_{2} \mathrm{O}}$ without appreciably augmenting osmolar clearance $\left(\mathrm{C}_{\text {osm }}\right)$. $\mathrm{C}_{\mathrm{H}_{2} \mathrm{O}}$ was, therefore, analyzed as a function of $\mathrm{V}$, rather than $\mathrm{C}_{\mathrm{osm}}$, since $\mathrm{V}$ was the best estimate of delivery of filtrate to the diluting segment. $\mathrm{C}_{\mathrm{H}_{2} \mathrm{O}}$ increased as a linear function of $\mathrm{V}$ without any evidence of saturation.

The validity of interpreting increases in $\mathrm{C}_{\mathrm{H}_{2} \mathrm{O}}$ and $\mathrm{V}$ as indications of increased sodium reabsorption and delivery was reinforced by tissue studies that disclosed a rise in papillary osmolality with rising urine flows. The observed increase in $\mathrm{C}_{\mathrm{H}_{2} \mathrm{O}}$ and $\mathrm{V}$ could not, therefore, be due to a decrease in back diffusion of solute-free water as a result of a diminished osmotic driving force, but probably represented increased formation consequent to augmented delivery as a result of decreased fractional reabsorption in the proximal tubule.

In animals whose extracellular volume was acutely or chronically overexpanded before the infusion of hypotonic saline, sodium excretion was greater, and $\mathrm{C}_{\mathrm{H}_{2} \mathrm{O}}$ less, at any given $\mathrm{V}$. Although the curve relating $\mathrm{C}_{\mathrm{H}_{2} \mathrm{O}}$ to $\mathrm{V}$ was flatter than in the control group, no tubular maximum was observed. The diminished $\mathrm{C}_{\mathrm{H}_{2} \mathrm{O}}$ in this group was interpreted to mean that massive expansion of extracellular volume inhibits sodium reabsorption in the ascending limb of Henle's loop.

\section{Introduction}

It is now well established that the principal process mediating the concentration and dilution

* Submitted for publication September 13, 1966; accepted March 22, 1967.

Supported in part by grants 5-SOI FR-5426-05 and 5-TI HE-5469 from the National Institutes of Health and in part by a grant from the Dallas Heart Association.

$\dagger$ Address requests for reprints to Dr. Donald W. Seldin, Dept. of Internal Medicine, University of Texas of urine is the reabsorption of sodium in a waterimpermeable segment of the nephron. In consequence, the clearance of solute-free water $\left(\mathrm{C}_{\mathrm{H}_{2} \mathrm{O}}\right)$ and the reabsorption of solute-free water $\left(\mathrm{T}^{\mathrm{c}} \mathrm{H}_{2} \mathrm{O}\right)$ reflect principally the magnitude of sodium reabsorption in the ascending limb. It is possible, therefore, that measurement of these parameters

Southwestern Medical School, 5223 Harry Hines Blvd., Dallas, Texas 75235 . 
may permit a characterization of sodium reabsorption in this segment.

The use of $\mathrm{T}^{\mathbf{c}} \mathrm{H}_{2} \mathrm{O}$ as an index of sodium reabsorption in the ascending limb has proved hazardous. Previous studies in this laboratory (1) and by Goodman, Cohen, Levitt, and Kahn (2) have indicated that with increasing solute clearance in the $\operatorname{dog} \mathrm{T}^{\mathbf{c}}{ }_{\mathrm{H}_{2} \mathrm{O}}$, instead of rising or remaining unchanged, actually diminishes and finally becomes negative. This is doubtless a result of the fact that distal tubular fluid in the dog is always hypotonic (3). As solute diuresis mounts, therefore, delivery of hypotonic fluid into the medullary portion of the collecting duct results in a calculated value for $\mathrm{T}^{\mathrm{c}}{ }_{\mathrm{H}_{2} \mathrm{O}}$ that is falsely low and does not reflect the full extent of water reabsorption (1). $\mathrm{T}^{\mathrm{c}}{ }_{\mathrm{H}_{2} \mathrm{O}}$ will thus tend to underestimate to an unpredictable extent the magnitude of sodium reabsorption in the ascending limb during rapid rates of solute diuresis.

$\mathrm{C}_{\mathrm{H}_{2} \mathrm{O}}$ is a better index of sodium reabsorption in the ascending limb, since the low water permeability in the distal tubule is actually an advantage. It has been established in several studies $(4,5)$ that $\mathrm{C}_{\mathrm{H}_{2} \mathrm{O}}$ depends principally on the load of sodium delivered to the diluting segment. However, as sodium delivery is increased, usually by mannitol infusion, a maximum for $\mathrm{C}_{\mathrm{H}_{2} \mathrm{O}}$ is reached beyond which no further free water can be generated despite increasing solute excretion $(6,7)$. These studies, however, suffer from the disadvantage that $\mathrm{C}_{\mathrm{H}_{2} \mathrm{O}}$ was measured over a comparatively narrow range of solute clearance $\left(\mathrm{C}_{\mathrm{osm}}\right)$. Moreover, the use of mannitol has a serious disadvantage. Mannitol will depress the concentration of sodium delivered to the diluting segment, thereby placing a concentration limit on the amount of sodium that can be reabsorbed in the ascending limb independent of the intrinsic capacity. In other studies (8) the use of diuretics to assess $\mathrm{C}_{\mathrm{H}_{2} \mathrm{O}}$ is especially unreliable, since the diuretics may themselves impair sodium transport in the diluting segment. For these reasons the characterization of sodium transport in the ascending limb using $\mathrm{C}_{\mathrm{H}_{2} \mathrm{O}}$ has not been entirely satisfactory.

We have attempted to circumvent these diffculties by using saline diuresis as a means of increasing delivery of sodium to the ascending limb. Control studies were first performed in which $\mathrm{C}_{\mathrm{H}_{2} \mathrm{O}}$ was examined over a wide range of sodium de- livery, which was accomplished by hypotonic saline infusions. The influences of a variety of factors that might affect $\mathrm{C}_{\mathrm{H}_{2} \mathrm{O}}$ independent of delivery-hyponatremia, medullary blood flow, effective extracellular fluid (ECF) volume-could then be identified.

\section{Methods}

Studies were performed on female mongrel dogs weighing 10 to $18 \mathrm{~kg}$ fed regular commercial diets. The same general procedure was followed in all studies.

On the day of study an indwelling urethral catheter was inserted under mild thiopental sodium anesthesia; while still anesthetized all dogs were given $500 \mathrm{ml}$ of water by stomach tube; thereafter the dogs were allowed to awaken. Water diuresis was maintained by the infusion of $0.45 \%$ sodium chloride, which was started at rates of $6 \mathrm{ml}$ per minute and increased thereafter to rates up to 40 to $50 \mathrm{ml}$ per minute. The rate of infusion was such that it always exceeded urine flow rate by $5 \mathrm{ml}$ per minute. Since the experiments lasted 3 to 4 hours the positive balance of hypotonic saline at the end of the experiment was 900 to $1,200 \mathrm{ml}$. Four dogs were infused, in addition, with $2.5 \%$ glucose solution at 4 to 6 $\mathrm{ml}$ per minute throughout the entire experiment to ensure the development of pronounced hyponatremia. Urinary collection periods were 15 minutes, and arterial blood samples were drawn from an indwelling Cournand needle in the femoral artery at the midpoint of each collection period. After an appropriate loading dose, a sustaining infusion of inulin and para-aminohippurate (PAH) in normal saline was given at about $2 \mathrm{ml}$ per minute. Enough potassium chloride was added to this infusion to deliver $90 \mu \mathrm{Eq}$ per minute of potassium, in order to compensate for the potassium loss sustained during the massive diuresis that ensued.

In the first series of experiments $\mathrm{C}_{\mathrm{H}_{2} \mathrm{O}}$ was studied in 4 groups of animals during hypotonic saline diuresis. Group I consisted of 4 normal dogs. Group II consisted of 14 dogs pretreated for 7 days with an im injection of deoxycorticosterone acetate (DOCA), 1 to $2 \mathrm{mg}$ per $\mathrm{kg}$ body weight daily. The diet was supplemented with 5 to $10 \mathrm{~g}$ potassium chloride daily to prevent hypokalemia. Group III consisted of 3 unilaterally nephrectomized dogs, similarly treated with DOCA. Group IV consisted of 3 normal dogs infused with 2 to $3 \mathrm{~L}$ of isotonic saline over a 5-hour period immediately preceding water administration and hypotonic saline infusion.

In the second series of experiments renal hemodynamics were studied in normal and DOCA-treated animals. The animals were prepared 2 to 3 weeks before the study. The left kidney and renal vein were exposed through an abdominal incision, and the left ovarian vein was ligated and cut. A Teflon catheter was then introduced into the left renal vein through the inferior vena cava and connected with a silastic catheter filled with heparinized saline. The free end of the silastic catheter was tied 
with umbilical tape and implanted subcutaneously in the subcostal abdominal wall. On the day of study, after induction of a water diuresis, the free end of the silastic catheter was freed, flushed with saline, and used for obtaining samples of left renal venous blood. Under light pentobarbital anesthesia the right ureter was exposed through a flank incision and cannulated with polyethylene tubing. Urine samples from the left kidney were obtained from the bladder. Arterial and venous blood samples were collected simultaneously into heparinized syringes, transferred to ice-cooled tubes, and immediately centrifuged at $4^{\circ} \mathrm{C}$ in a refrigerated Sorvall centrifuge to prevent leakage of PAH from red blood cells.

In the third series of experiments the effect of water diuresis and hypotonic saline diuresis on medullary tonicity was studied by tissue analysis. After induction of water diuresis or hypotonic saline diuresis, the dogs were anesthetized with pentobarbital, and a minimum of two consecutive collection periods with stable urine flow and osmolality was obtained before the kidneys were removed. The kidneys were sectioned transversely; the cortex, outer medulla, and inner medulla were identified by gross anatomic characteristics and random pieces of each taken for analysis. The tissue slices were blotted on filter paper and weighed. They were then dried under vacuum at $60^{\circ} \mathrm{C}$ for 36 hours and weighed again. The difference in weight was considered the water content. Each dried tissue sample was ground, made up to a volume of $10 \mathrm{ml}$ with demineralized water, allowed to stand overnight, and then autoclaved at $120^{\circ} \mathrm{C}$ under a pressure of 15 pounds per square inch for 2 hours. The samples were centrifuged and portions of the supernate taken for sodium and potassium analysis. Urea was initially analyzed both on fresh and homogenized samples, but was negligible, and was therefore not determined in later studies.

Inulin was analyzed by the method of Walser, Davidson, and Orloff (9), PAH by the method of Smith and co-workers (10), as adapted for the Technicon Autoanalyzer. Serum and urinary sodium and potassium were determined by internal standard flame photometry as modified for the Autoanalyzer. Plasma and urinary osmolality were measured on the Fiske osmometer.

$\mathrm{C}_{\mathrm{osm}}$ and $\mathrm{C}_{\mathrm{H}_{2} \mathrm{O}}$ were calculated in the usual fashion and expressed per $100 \mathrm{ml}$ glomerular filtrate for the purpose of comparing results from different experiments. Total renal plasma flow (RPF) was calculated from the formula of Wolf (11): RPF $=\mathrm{V}(\mathrm{U}-\mathrm{R}) /(\mathrm{A}-\mathrm{R})$, where $\mathrm{V}$ is urine flow and $\mathrm{U}, \mathrm{R}$, and $\mathrm{A}$, the $\mathrm{PAH}$ concentration of the urinary, renal venous, and arterial samples, respectively. Clearance of $\mathrm{PAH}\left(\mathrm{C}_{\mathbf{P A B}}\right)$ was assumed to approximate renal cortical plasma flow, and noncortical plasma flow (NCPF) calculated from the difference between RPF and $\mathrm{C}_{\mathbf{P A B}}$. Noncortical blood flow has been widely used as an estimate of medullary blood flow (12, 13). Papillary osmolality was calculated as twice the sum of the concentrations of sodium and potassium in tissue water. Concentration of urea, in all experiments in which it was measured, was found to be negligible and therefore not included in these calculations.

\section{Results}

Effect of hypotonic saline infusion on electrolyte and water excretion. The first series of studies concerns the effects of hypotonic saline infusion in normal dogs (group I). The protocol of a representative experiment is presented in Table $I(\operatorname{dog} M)$. With infusion of hypotonic saline, $V$ rose, urinary osmolality ( $\mathrm{U}_{\mathrm{osm}}$ ) fell slightly, $\mathrm{C}_{\text {osm }}$ rose only slightly, and $\mathrm{C}_{\mathrm{H}_{2} \mathrm{O}}$ rose sharply. The glomerular filtration rate (GFR) was relatively stable. Sodium excretion increased from 10 to $167 \mu$ Eq per minute.

The results of the group as a whole are charted in Figure 1. $\mathrm{C}_{\mathrm{H}_{2} \mathrm{O}}$ is plotted as a function of $\mathrm{C}_{\mathrm{osm}}$ and $\mathrm{V}$. As $\mathrm{V}$ mounted to a maximum of $17.8 \mathrm{ml}$ per minute per $100 \mathrm{ml}$ GFR, $\mathrm{C}_{\mathrm{H}_{2} \mathrm{O}}$ rose sharply from 6.3 to $15.0 \mathrm{ml}$ per minute per $100 \mathrm{ml} \mathrm{GFR}$. This rise in $\mathrm{C}_{\mathrm{H}_{2} \mathrm{O}}$ was associated with only a minimal increase in $\mathrm{C}_{\text {osm }}$ from 1.3 to $3.1 \mathrm{ml}$ per minute per $100 \mathrm{ml} \mathrm{GFR}$. Despite continued high rates of infusion it was impossible to increase $\mathrm{C}_{\text {osm }}$ beyond $3.1 \%$ of GFR. No maximum for $\mathrm{C}_{\mathrm{H}_{2} \mathrm{O}}$ could be detected, although the range of $\mathrm{C}_{\mathrm{osm}}$ admittedly was small.

The infusion of hypotonic saline into normal animals, though associated with a marked rise in $\mathrm{V}$ and $\mathrm{C}_{\mathrm{H}_{2} \mathrm{O}}$, produces only a slight absolute increase in $\mathrm{Na}$ excretion, although the relative rise is great (Table I). The increase in $\mathrm{V}$ cannot reasonably be attributed to further suppression of antidiuretic hormone secretion. During the initial period, the concentration of serum sodium was low, ECF volume was expanded, and the urine was maxi-

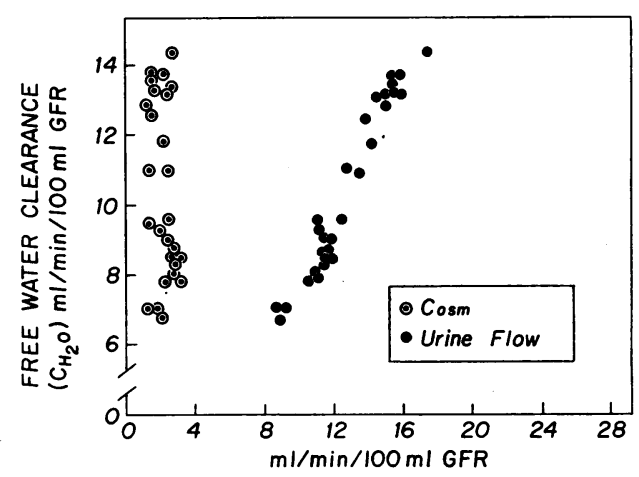

Fig. 1. The fractional Clearance of solute-free WATER ( $\mathrm{C}_{\mathrm{H}_{2} \mathrm{O}}$ ) PLOTTED AGAINST FRACTIONAL OSMOLAR CLEARANCE (Cosm) AND AGAINST FRACTIONAL URINE FLOW IN UNTREATED CONTROL DOGS. 
FUNCTIONAL CHARACTERISTICS OF THE DILUTING SEGMENT

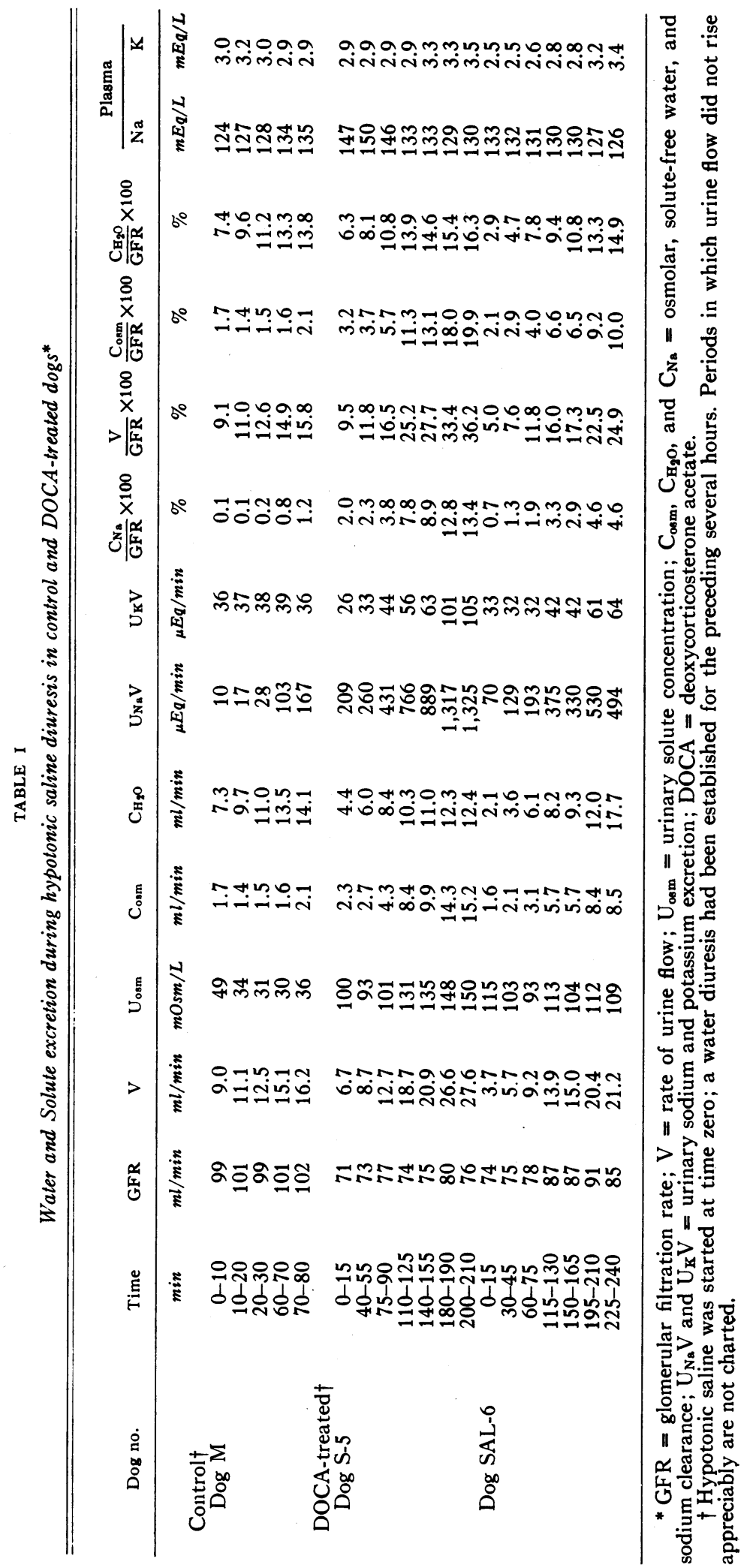


mally hypotonic. It is, therefore, much more reasonable to attribute the rise in $\mathrm{V}$ to increased free water formation resulting from suppression of proximal reabsorption because of expansion of extracellular volume with hypotonic saline. The amount of saline given is in excess of that shown by micropuncture studies to reduce the ratio of tubular fluid to plasma inulin at the end of the proximal tubule (14). The failure of sodium excretion to rise greatly as urine flow mounts is probably the result of hyponatremia. Ample evidence exists that the concentration of serum sodium per se influences sodium reabsorption (15). The present studies constitute strong evidence that the site in the nephron where hyponatremia stimulates $\mathrm{Na}$ reabsorption is the ascending limb of Henle's loop.

Because of the difficulty in the preceding experiments in achieving sufficiently high rates of $\mathrm{C}_{\text {osm }}$ and $\mathrm{V}$ to evaluate $\mathrm{C}_{\mathrm{H}_{2} \mathrm{O}}$ adequately, the studies were repeated in animals treated chronically with DOCA (group II). Animals treated in this fashion are known to have an enhanced sodium excretion in response to saline infusion. The results of such an experiment are presented in Table I ( $\operatorname{dog} \mathrm{S}-5)$. The infusion of hypotonic saline into the DOCA-treated dog resulted in much higher fractional urine flows $(\mathrm{V} / \mathrm{GFR} \times 100)$ and fractional $\mathrm{C}_{\text {osm }}\left(\mathrm{C}_{\text {osm }} / \mathrm{GFR} \times 100\right)$ than were achieved in the normal $\operatorname{dog}(\operatorname{dog} M)$.

The data for the entire DOCA-treated group (group II) are plotted in Figure 2. In contrast to the normal dogs $\mathrm{C}_{\mathrm{osm}}$ ranged from 3.2 to as

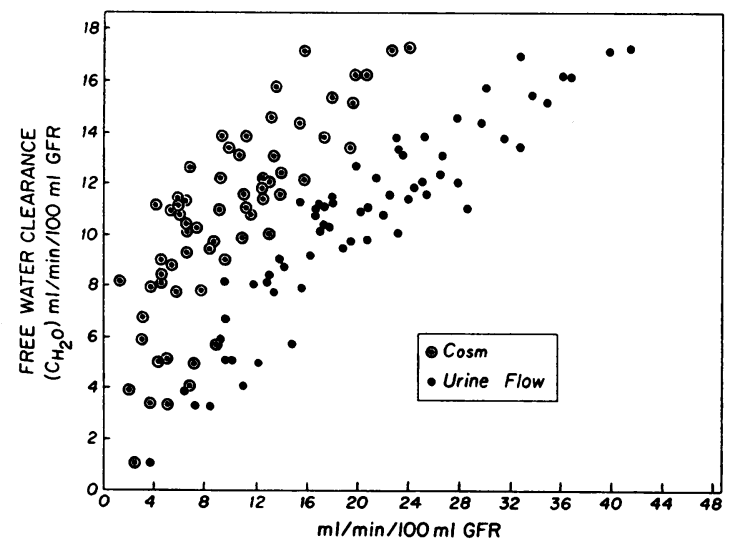

Fig. 2. The fractional clearance of $\mathrm{C}_{\mathrm{H}_{2} \mathrm{O}}$ plotted AGAINST FRACTIONAL Cosm AND AGAINST FRACTIONAL URINE FLOW IN DOCA-TREATED DOGS.

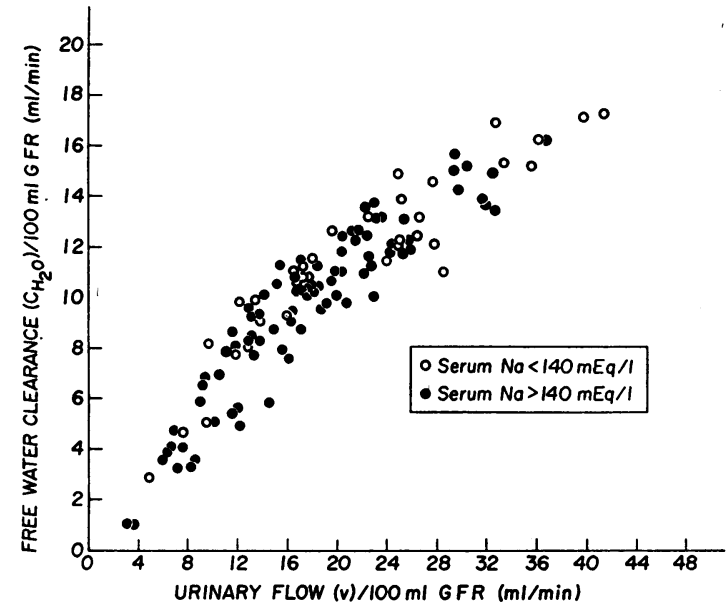

Fig. 3. The effect of serum concentration on the RELATION OF FRACTIONAL $\mathrm{C}_{\mathrm{H}_{2} \mathrm{O}}$ TO FRACTIONAL URINE FLOW (V) IN DOCA-TREATED DOGS.

high as $24 \mathrm{ml}$ per minute per $100 \mathrm{ml} \mathrm{GFR}$, and V ranged from 4 to $41 \mathrm{ml}$ per minute per $100 \mathrm{ml}$ GFR. Fractional $\mathrm{C}_{\mathrm{H}_{2} \mathrm{O}}$, however, was only slightly greater (17.2) than in the normal animals (15.0, Figure 1). Even with this massive increase in $\mathrm{C}_{\mathrm{osm}}$, no maximum for $\mathrm{C}_{\mathrm{H}_{2} \mathrm{O}}$ could be demonstrated. To determine whether the lower $\mathrm{C}_{\mathrm{H}_{2} \mathrm{O}}$ with DOCA-treated dogs as compared to control animals at any given $\mathrm{V}$ was the result of inadequate hydration, we performed studies on DOCAtreated dogs infused with $2.5 \%$ dextrose solution at the rate of 4 to $6 \mathrm{ml}$ per minute for 3 to 4 hours before the onset of the study. The results of one such experiment are shown at the bottom of $\mathrm{Ta}$ ble I (dog SAL-6). Despite marked hyponatremia, $\mathrm{U}_{\text {osm }}$ was comparatively higher and $\mathrm{C}_{\mathrm{H}_{2} \mathrm{O}}$ lower at any level of $\mathrm{V}$ than in the untreated control $\operatorname{dog}(\operatorname{dog} M)$. Moreover, these results were quite comparable to those of the DOCA-treated animal with the higher serum sodium concentration (dog S-5). Indeed a comparison of the DOCA-treated dogs with concentrations of serum sodium above and below $140 \mathrm{mEq}$ per L (Figure 3 ) discloses no influence of the concentration of serum sodium on the relation between $\mathrm{C}_{\mathrm{H}_{2} \mathrm{O}}$ and $\mathrm{V}$. This is strong evidence of maximal suppression of antidiuretic hormone secretion in all the DOCA-treated animals.

In an attempt to increase still further the solute load per nephron to ascertain whether a maximum for $\mathrm{C}_{\mathrm{H}_{2} \mathrm{O}}$ could be reached, 3 DOCA-treated dogs 
were studied 3 to 6 weeks after unilateral nephrectomy to allow for the compensatory hypertrophy and increase in GFR in the remaining kidney (group III). The effect of hypotonic saline infusion on $\mathrm{C}_{\mathrm{H}_{2} \mathrm{O}}$ per $100 \mathrm{ml}$ GFR is plotted in Figure 4 (open triangles), where the shaded area is taken from the results in Figure 2 comparing $\mathrm{C}_{\mathrm{H}_{2} \mathrm{O}}$ and $\mathrm{V}$. All the points from the unilaterally nephrectomized dogs fell within the shaded area, indicating that despite increased GFR per nephron (16), the relation between $\mathrm{C}_{\mathrm{H}_{2} \mathrm{O}}$ and $\mathrm{V}$ was unchanged.

It is apparent from Figures 1 and 2 that $\mathrm{C}_{\mathrm{H}_{2} \mathrm{O}}$, at any given $\mathrm{C}_{\text {osm }}$ or $\mathrm{V}$, is higher in the normal than in the DOCA-treated dogs. In Figure 5 the greater $\mathrm{C}_{\mathrm{H}_{2} \mathrm{O}}$ at any given $\mathrm{V}$ in the control animals (crosshatched) than in the DOCA-treated animals (stippled) is more clearly illustrated. To determine whether the difference between the normal and DOCA-treated group was an effect of DOCA or of volume expansion, we studied $\mathrm{C}_{\mathrm{H}_{2} \mathrm{O}}$ in 3 nonDOCA treated dogs (group IV) immediately after volume expansion by isotonic saline (Figure 5 , closed triangles). The response of all 3 animals differed from the normal group and was the same as in the DOCA-treated group. This is strong evidence that the effects of chronic DOCA treatment on $\mathrm{C}_{\mathrm{H}_{2} \mathrm{O}}$ are attributable to extracellular volume expansion, not to DOCA per se. Further evidence that DOCA per se has no effect on the diluting segment was obtained in experiments (not

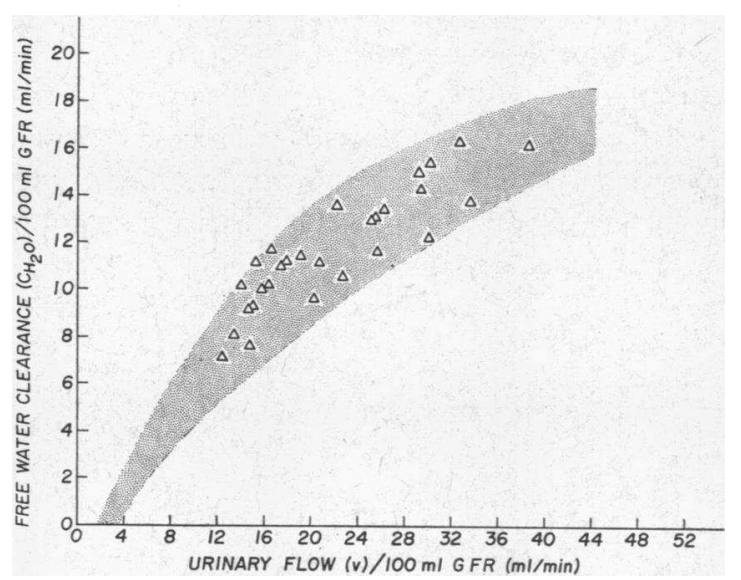

Fig. 4. The efFEct OF UNILATERAL NEPHRECTOMY ON The Relation of Fractional $\mathrm{C}_{\mathrm{H}_{2} \mathrm{O}}$ to fractional $\mathrm{V}$. The stippled area represents the relation of $\mathrm{C}_{\mathrm{H}_{2} \mathrm{O}}$ to $\mathrm{V}$ in intact DOCA-treated dogs (Figure 2).

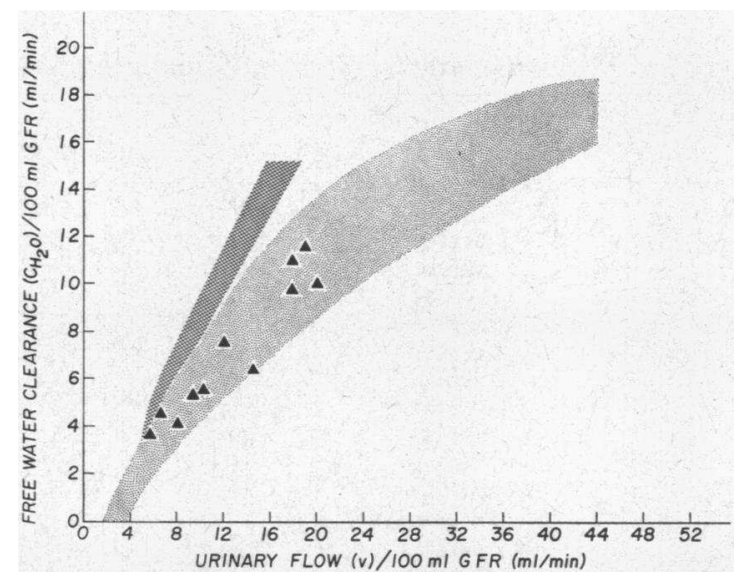

Fig. 5. The EFFect of PRIOR EXtracellular volume EXPANSION WITH ISOTONIC SALINE ON THE RELATION OF FRACTIONAL $\mathrm{C}_{\mathrm{H}_{2} \mathrm{O}}$ TO FRACTIONAL $\mathrm{V}$ IN DOGS NOT TREATED WITH DOCA. The stippled and crosshatched areas represent the relation of $\mathrm{C}_{\mathrm{H}_{2} \mathrm{O}}$ to $\mathrm{V}$ in DOCA-treated and control dogs, respectively.

here presented) in which the acute administration of DOCA to group I animals resulted in the same relation of $\mathrm{C}_{\mathrm{H}_{2} \mathrm{O}}$ to $\mathrm{V}$ as is detailed in Figure 1 .

Effect of hypotonic saline on renal hemodynamics. To investigate the role of medullary blood flow during hypotonic saline infusion and extracellular volume expansion, we measured $\mathrm{PAH}$ extraction ratios and calculated renal plasma flow in 6 experiments. The results obtained in 5 DOCA-treated and 1 normal dogs are summarized in Table II, where the period of maximal urine flow in water diuresis and hypotonic saline diuresis is compared. With hypotonic saline loading, there was an increase in PAH clearance and renal plasma flow, and a fall in the extraction of PAH. The calculated noncortical blood flow uniformly increased.

Effect of hypotonic saline infusions on renal tissue composition. Expansion of the extracellular fluid volume, by increasing medullary blood flow (Table II), might cause a washout of medullary tonicity (13), thereby markedly reducing the back diffusion of solute-free water out of the collecting duct. To evaluate the possible role of medullary washout on $\mathrm{C}_{\mathrm{H}_{2} \mathrm{O}}$, we measured the composition of renal tissue at varying rates of diuresis in 18 experiments, 15 on DOCA-treated and 3 on untreated control dogs. The results of tissue analysis of these 2 groups were indistin- 
TABLE II

Renal hemodynamic changes during hypotonic saline diuresis in control and DOCA-treated dogs*

\begin{tabular}{|c|c|c|c|c|c|c|c|}
\hline $\begin{array}{l}\text { Dog } \\
\text { no. }\end{array}$ & & $\mathrm{V}$ & GFR & $\mathrm{C}_{\mathbf{P A H}}$ & RPF & EPAR & NCPF \\
\hline & & $\mathrm{ml} / \mathrm{min}$ & $m l / m i n$ & $\mathrm{ml} / \mathrm{min}$ & $\mathrm{ml} / \mathrm{min}$ & $\%$ & $\mathrm{ml} / \mathrm{min}$ \\
\hline \multirow[t]{2}{*}{ P-1 } & Water & 5.9 & 78 & 208 & 311 & 66 & 103 \\
\hline & Saline & 21.3 & 116 & 290 & 440 & 64 & 150 \\
\hline \multirow[t]{2}{*}{ P-2 } & Water & 2.4 & 40 & 95 & 112 & 85 & 17 \\
\hline & Saline & 6.4 & 37 & 109 & 145 & 74 & 36 \\
\hline \multirow[t]{2}{*}{ P-3 } & Water & 4.3 & 32 & 76 & 105 & 71 & 29 \\
\hline & Saline & 10.6 & 41 & 139 & 241 & 56 & 102 \\
\hline \multirow[t]{2}{*}{ P-4 } & Water & 3.4 & 42 & 112 & 190 & 58 & 78 \\
\hline & Saline & 7.2 & 46 & 174 & 368 & 46 & 194 \\
\hline \multirow[t]{2}{*}{ P-5 } & Water & 3.3 & 26 & 52 & 69 & 74 & 17 \\
\hline & Saline & 5.9 & 30 & 75 & 105 & 69 & 30 \\
\hline \multirow[t]{2}{*}{ P-7 } & Water & 2.2 & 28 & 54 & 64 & 84 & 10 \\
\hline & Saline & 6.0 & 30 & 79 & 103 & 75 & 24 \\
\hline
\end{tabular}

$* \mathrm{C}_{\mathrm{PAH}}=$ clearance of para-aminohippurate $; \mathrm{RPF}=$ renal plasma flow $; \mathrm{E}_{\mathrm{PAB}}=\mathrm{PAH}$ extraction ratio; $\mathrm{NCPF}$ $=$ noncortical plasma flow. See Table $I$ for other abbreviations. The values on dogs P-2 to P-7 are those obtained from the left kidney; only the left kidney was cannulated for the measurement of PAH extraction. In the experiment on dog P-1 only bladder urine was collected. The blood flow data were extrapolated from the extraction of PAH on the left side. Dog P-7 did not receive DOCA; dogs P-1 through P-5 did.

guishable and were plotted together. Figure 6 indicates that as urine flow was increased from 3.7 to $10 \mathrm{ml}$ per minute, papillary osmolality rose from 280 to $500 \mathrm{mOsm}$ per $\mathrm{kg}$ tissue water. With further increases in urine flow from 10 to $25 \mathrm{ml}$ per minute, papillary osmolality remained rela-

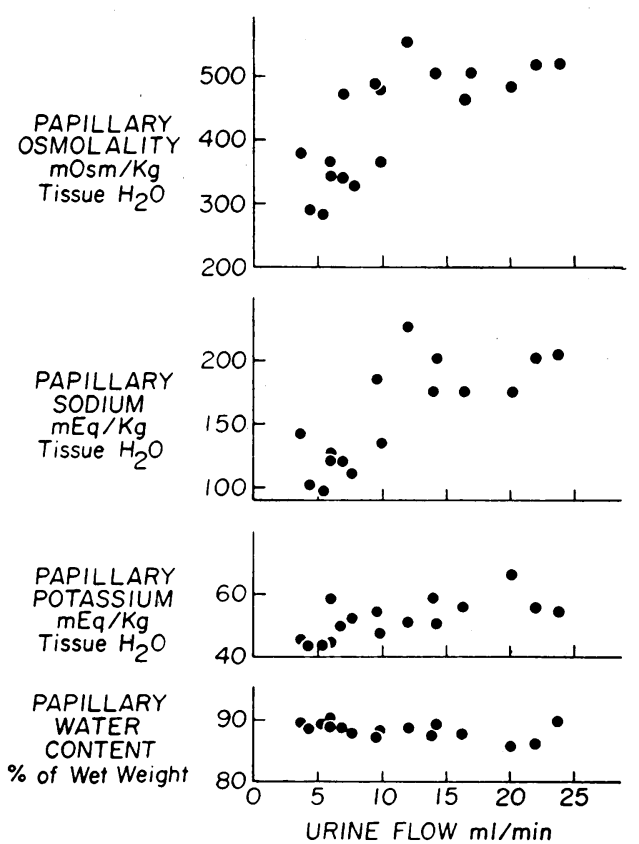

Fig. 6. THE EFFECT OF INCREASING URINE FLOW DURING HYPOTONIC SALINE DIURESIS ON THE ELECTROLYTE AND WATER CONTENT OF THE RENAL PAPILLA. tively constant. The increase in papillary osmolality as urine flow rose to $10 \mathrm{ml}$ per minute was almost entirely due to a rise in tissue sodium concentration. The potassium concentration showed only a minimal rise with increasing urine flows. Since the papillary water content remained constant throughout, the rise in papillary sodium concentration represents an accumulation of sodium in the medulla. Therefore, the increased medullary blood flow (Table II) did not affect a washout of medullary sodium.

Urinary osmolality 'tended to rise with the rise in urine flow, but not proportionately to the rise in papillary osmolality, so that when the osmotic gradient between papilla and urine is plotted against urine flow (in the 18 experiments in Figure 6) as shown in Figure 7, there is a gradual increase in osmotic gradient with increasing urine flow, from $178 \mathrm{mOsm}$ to $421 \mathrm{mOsm}$ per $\mathrm{kg}$ water.

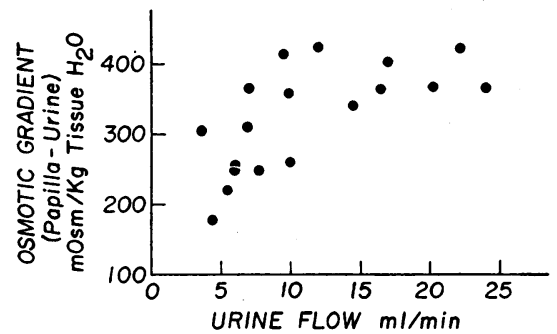

Fig. 7. THE EFFECT OF INCREASING URINE FLOW DURING HYPOTONIC SALINE DIURESIS ON THE OSMOTIC GRADIENT BETWEEN PAPILLARY WATER AND URINE. 


\section{Discussion}

The reabsorption of sodium in the diluting segment of the nephron is the principal factor responsible for $\mathrm{C}_{\mathrm{H}_{2} \mathrm{O}} . \mathrm{C}_{\mathrm{H}_{2} \mathrm{O}}$, in turn, is a function of both delivery of substrate (sodium) and the intrinsic reabsorptive characteristics of the diluting segment. The intrinsic characteristics of sodium reabsorption in this segment, therefore, can be delineated only as a function of delivery.

It is usual to express $\mathrm{C}_{\mathrm{H}_{2} \mathrm{O}}$ as a function of $\mathrm{C}_{\mathrm{osm}}$. However, $\mathrm{C}_{\text {osm }}$ represents the rate of excretion of unreabsorbed solute and bears no well-defined relation to sodium delivery. Figure 1 discloses that progressive hypotonic saline infusion elicits an increase in $\mathrm{C}_{\mathbf{H}_{2} \mathrm{O}}$ per $100 \mathrm{ml} \mathrm{GFR}$ from 6.3 to 15.0 with virtually no increase in $\mathrm{C}_{\text {osm }}$. This means that practically the entire increment in sodium delivery to the diluting segment is reabsorbed there, with only trivial amounts escaping into the urine. $\mathrm{C}_{\text {osm }}$, therefore, does not accurately reflect increasing delivery and consequently cannot be related to $\mathrm{C}_{\mathrm{H}_{2} \mathrm{O}}$. The same data are plotted as a function of V (Figure 1). Since very little water is lost from the distal nephron during water diuresis, $\mathrm{V}$ is a reasonable approximation of the quantity of sodium containing fluid reaching the diluting segment. An increase in fractional delivery (V) from 8 to 17.8 elicits a linear increase in sodium reabsorption $\left(\mathrm{C}_{\mathrm{H}_{2} \mathrm{O}}\right)$.

The use of $\mathrm{C}_{\mathrm{H}_{2} \mathrm{O}}$, in this manner, as an estimate of sodium reabsorption and $\mathrm{V}$ as an estimate of delivery is in error to the extent that back diffusion of solute-free water occurs in the distal nephron. The actual rate of solute-free water formation is equal, not to $\mathrm{C}_{\mathrm{H}_{2} \mathrm{O}}$, but to $\mathrm{C}_{\mathrm{H}_{2} \mathrm{O}}$ plus back diffusion. Similarly, the actual rate of delivery is equal, not to $\mathrm{V}$, but to $\mathrm{V}$ plus back diffusion. It is clear, therefore, that significant changes in back diffusion might influence the relation between $\mathrm{V}$ and $\mathrm{C}_{\mathrm{H}_{2} \mathrm{O}}$ independent of the actual rate of delivery and sodium reabsorption.

Back diffusion might change as a result of an alteration in the osmotic driving force or the permeability of the tubular epithelium to water.

Earley and Friedler have proposed (13) that saline diuresis elicits an increase in medullary blood flow, thereby causing a washout of medullary sodium. This might dissipate the osmotic force for the back diffusion of water out of the collecting duct. In this view the increase in $\mathrm{C}_{\mathrm{H}_{2} \mathrm{O}}$ as a function of $\mathrm{V}$ would represent, not increased formation with increasing delivery, but rather diminished back diffusion.

To examine whether a reduction in back diffusion could, as a result of a diminished osmotic gradient, account for the relation of $\mathrm{C}_{\mathrm{H}_{2} \mathrm{O}}$ to $\mathrm{V}$ during hypotonic saline infusion, we measured the composition of the inner renal medulla at varying rates of diuresis. The results of these studies are shown in Figures 6 and 7. As urine flow increased from 4 to $25 \mathrm{ml}$ per minute, the papillary osmolality increased from $280 \mathrm{mOsm}$ per kg tissue water to over $500 \mathrm{mOsm}$ per $\mathrm{kg}$ tissue water (Figure 6). This increase was entirely due to a rise in tissue sodium concentration; potassium remained relatively constant. Although urinary osmolality rose with the rise in urine flow, this rise was not proportionate to the rise in papillary osmolality. As a result, as shown in Figure 7, the osmotic gradient between papilla and urine increased. These increases in papillary osmolality and in the osmotic gradient between the papilla and urine occurred despite a significant rise in noncortical blood flow (Table II). It is evident, therefore, that increased medullary blood flow during hypotonic saline diuresis does not effectively accelerate net medullary washout, since the osmotic gradient between the papilla and urine actually increases in the face of increasing noncortical blood flow. We therefore conclude that the observed increase in $\mathrm{C}_{\mathrm{H}_{2} \mathrm{O}}$ and $\mathrm{V}$ cannot be due to a diminution in the driving force for water back diffusion in the medulla.

It is more difficult to define the role of a change in water permeability. It is possible that expansion of ECF diminishes the permeability of the distal nephron to the back diffusion of water. If this were so, the increased $\mathrm{C}_{\mathrm{H}_{2} \mathrm{O}}$ and $\mathrm{V}$ during hypotonic saline diuresis would represent diminished back diffusion of water, not increased free water formation. The increased papillary solute concentration could then be regarded as the consequence of diminished entry of water into the medulla and reduced solute removal.

However, since extracellular volume expansion has been shown to increase delivery of filtrate to the diluting segment by suppressing proximal tubular reabsorption $(14,17)$ and since the increase in sodium excretion was slight (Table $I, \operatorname{dog} M$ ), 
it follows that almost all of the increment of sodium must have been reabsorbed in the diluting segment. An increase in free water formation, urine flow, and medullary sodium concentration, therefore, would result from increased delivery without invoking changes in permeability. That some of the increased free water might have resulted from diminished back diffusion as a result of impaired permeability cannot be excluded. There is, however, no need to postulate a separate new effect of extracellular volume expansion on permeability for which there is no independent evidence. The increased $\mathrm{C}_{\mathrm{H}_{2} \mathrm{O}}$ and $\mathrm{V}$ during hypotonic saline diuresis, accordingly, appear to represent principally increased free water formation as delivery is augmented. $\mathrm{C}_{\mathbf{H}_{2} \mathrm{O}}$ then appears to be a reasonable estimate of sodium reabsorption in, and $\mathrm{V}$ a reasonable estimate of delivery to, the diluting segment.

It is clear from Figure 1 that sodium reabsorption in the diluting segment $\left(\mathrm{C}_{\mathrm{H}_{2} \mathrm{O}}\right)$ increases as a linear function of delivery (V) without any evidence of saturation. These results differ from previous studies in which a maximum for $\mathrm{C}_{\mathrm{H}_{2} \mathrm{O}}$ was demonstrated with progresive solute diuresis $(6,7,18)$. Part of the disparity may be attributable to the use of nonreabsorbable solute (mannitol) as a means of increasing delivery. When mannitol is used to induce solute diuresis, the concentration of sodium reaching the ascending limb is sharply reduced. This could impose a ceiling on sodium reabsorption independent of the intrinsic reabsorptive properties of the tubule and may explain the maximum for $\mathrm{C}_{\mathrm{H}_{2} \mathrm{O}}$ achieved during mannitol diuresis.

It is also possible that a maximum ( $\mathrm{Tm}$ ) for $\mathrm{C}_{\mathrm{H}_{2} \mathrm{O}}$ was not achieved in the present studies (Figure 1) because delivery could be increased only moderately.' By expanding ECF volume chronically with DOCA plus sodium chloride, we were able to achieve much higher rates of delivery to the ascending limb (Figure 2). Although the relation of $\mathrm{C}_{\mathrm{H}_{2} \mathrm{O}}$ to $\mathrm{V}$ is curvilinear, no evidence of a $\mathrm{Tm}$ for $\mathrm{C}_{\mathrm{H}_{2} \mathrm{O}}$ was obtained, despite an increase in delivery up to $42 \%$ of the GFR. Further support for the absence of an intrinsic tubular maximum for $\mathrm{C}_{\mathrm{H}_{2} \mathrm{O}}$ is obtained from the experiments on dogs with unilateral nephrectomy. The adaptive increase in GFR per nephron of 60 to $70 \%$ results in near doubling of the absolute rate of delivery to the diluting segment at any given fractional rate of urine flow. Even at this enhanced rate of sodium delivery no limitation on $\mathrm{C}_{\mathrm{H}_{2} \mathrm{O}}$ was observed (Figure 4). We, therefore, conclude that the intrinsic mechanism for sodium reabsorption in the diluting segment exhibits no $\mathrm{Tm}$ even when rates of delivery are increased to as high as $42 \%$ of the GFR

A comparison of the relation between $\mathrm{C}_{\mathrm{H}_{2} \mathrm{O}}$ and $\mathrm{V}$ with and without DOCA (Figure 5, shaded areas) discloses that $\mathrm{C}_{\mathrm{H}_{2} \mathrm{O}}$ is less at any given $\mathrm{V}$ in the DOCA-treated than in the untreated control animals. Three factors might explain the altered relation between $\mathrm{C}_{\mathrm{H}_{2} \mathrm{O}}$ and $\mathrm{V}$ in the DOCAtreated dogs: hypernatremia, DOCA per se, and ECF volume expansion. Chronic treatment with DOCA tended to produce hypernatremia. Since several investigators $(19,20)$ have demonstrated an over-all suppression of sodium reabsorption by hypernatremia, it is conceivable that this effect occurs in the distal nephron and, therefore, might account for the augmented sodium excretion and diminished $\mathrm{C}_{\mathrm{H}_{2} \mathrm{O}}$ at any given rate of delivery in the DOCA-treated group. This possibility was excluded by forcing massive amounts of water to DOCA-treated animals, thereby reducing the serum sodium to levels observed in the untreated animals; nevertheless, the same depression in $\mathrm{C}_{\mathrm{H}_{2} \mathrm{O}}$ per unit delivery persisted (Figure 3 and Table I, dog SAL-6).

There was no evidence that hypernatremia in the DOCA-treated animals reduced $\mathrm{C}_{\mathrm{H}_{2} \mathrm{O}}$ by eliciting the secretion of vasopressin. The reduction in the serum sodium concentration to very low values by forcing water in the DOCA'-treated group did not alter the relation between $\mathrm{C}_{\mathrm{H}_{2} \mathrm{O}}$ and $\mathrm{V}$. The failure of hypernatremia to influence $\mathrm{C}_{\mathrm{H}_{2} \mathrm{O}}$ was not due to a refractoriness of the tubule to vasopressin. In unpublished studies we have demonstrated that injection of minute amounts of vasopressin to DOCA-treated animals at the height of hypotonic saline diuresis promptly results in a rise in urine concentration. We, therefore, conclude that the overexpansion of ECF volume in DOCA-treated animals given hypotonic saline suppresses vasopressin secretion even during hypernatremia. This is in accord with the demonstration by Arndt (21) that small changes in volume can override the effect of the concentration of serum sodium on antidiuretic hormone secretion. 
Conceivably, DOCA per se might inhibit sodium reabsorption, perhaps by competing with some more potent mineralocorticoid. The fact that the acute administration of DOCA to normal dogs during hypotonic saline diuresis did not depress $\mathrm{C}_{\mathrm{H}_{2} \mathrm{O}}$ is strong evidence that DOCA as such was not exerting an inhibitory effect on the diluting segment.

Finally, the reduced $\mathrm{C}_{\mathrm{H}_{2} \mathrm{O}}$ at any given $\mathrm{V}$ in the DOCA-treated dogs might be the consequence of volume expansion. The results from experiments in which ECF was acutely expanded in the absence of DOCA strongly support this hypothesis. The administration of $3 \mathrm{~L}$ of isotonic saline immediately before the free water study resulted in the same depression in $\mathrm{C}_{\mathrm{H}_{2} \mathrm{O}}$ as was observed in animals pretreated with DOCA (Figure 5).

This depression of $\mathrm{C}_{\mathrm{H}_{2} \mathrm{O}}$ by chronic DOCA treatment could result from increased back diffusion of water in the collecting duct or diminished free-water formation in the diluting segment. An effect on permeability seems unlikely. As mentioned earlier volume expansion has already been demonstrated to inhibit sodium reabsorption in the proximal tubule, and it seems reasonable to assume, therefore, that the same process inhibiting sodium transport may be operative in the diluting segment rather than to postulate a special additional effect on permeability. In support of the hypothesis that volume expansion is suppressing free water by diminishing sodium reabsorption in the diluting segment is the observation that the DOCA-treated dogs respond to hypotonic saline infusions with an increase in both sodium excretion and $\mathrm{C}_{\mathrm{H}_{2} \mathrm{O}}$. In the untreated animals hypotonic saline infusions increased $\mathrm{C}_{\mathrm{H}_{2} \mathrm{O}}$ with very little changes in sodium excretion (Table I). The fact that volume expansion in the DOCA-treated dogs suppresses $\mathrm{C}_{\mathrm{H}_{2} \mathrm{O}}$ at any given $\mathrm{V}$ and at the same time increases sodium excretion suggests that the site in the nephron where volume expansion suppresses sodium reabsorption is the diluting segment.

These results suggest that with modest volume expansion as is produced in the untreated animals by hypotonic saline infusion alone, sodium reabsorption is suppressed principally in the proximal tubule so that virtually all the increment of sodium delivered to the diluting segment is reabsorbed there and is reflected in increased $\mathrm{C}_{\mathrm{H}_{2} \mathrm{O}}$. With more massive volume expansion as in the DOCAtreated animals or in the animals acutely overexpanded with 2 to $3 \mathrm{~L}$ of isotonic saline, there is, in addition, suppression of sodium reabsorption in the diluting segment so that at any given $\mathrm{V}, \mathrm{C}_{\mathrm{H}_{2} \mathrm{O}}$ is less and sodium excretion is higher.

The ability of massive expansion of extracellular fluid volume to suppress sodium reabsorption in the diluting segment may explain the claim of several investigators $(6,7,17)$ that a $\mathrm{Tm}$ for $\mathrm{C}_{\mathrm{H}_{2} \mathrm{O}}$ exists. It is highly likely that an infusion of hypotonic saline, if continued long enough, would so greatly expand ECF volume that a Tm for $\mathrm{C}_{\mathrm{H}_{2} \mathrm{O}}$ might be obtained. Such a Tm would be the expression, not of any intrinsic limitation on sodium reabsorption in the diluting segment, but rather of progressive inhibition as a result of volume expansion.

We have used $\mathrm{C}_{\mathrm{H}_{2} \mathrm{O}}$ as an index of sodium reabsorption in the diluting segment without specifying the anatomic sites of this activity. As a first approximation the diluting segment might be defined as the area in the nephron which is water impermeable during maximal water diuresis and from which sodium is reabsorbed. This might, therefore, include the ascending limb, the distal convolution, and the collecting duct. Micropuncture studies in the rat (22) and the dog (3) have demonstrated that the osmotic pressure of the tubular fluid during water diuresis does not change from the beginning to the end of the distal convolution, and actually rises between the end of the distal convolution and the renal pelvis. This means that net $\mathrm{C}_{\mathrm{H}_{2} \mathrm{O}}$ must be formed almost entirely in the ascending limb. We therefore conclude that the suppression of $\mathrm{C}_{\mathrm{H}_{2} \mathrm{O}}$ by massive expansion of ECF volume means inhibition of sodium reabsorption in the thick ascending limb of Henle's loop.

\section{References}

1. Goldsmith, C., H. K. Beasley, P. J. Whalley, F. C. Rector, Jr., and D. W. Seldin. The effect of salt deprivation on the urinary concentrating mechanism in the dog. J. clin. Invest. 1961, 40, 2043.

2. Goodman, B., J. A. Cohen, M. F. Levitt, and M. Kahn. Renal concentration in the normal dog: effect of an acute reduction in salt excretion. Amer. J. Physiol. 1964, 206, 1123.

3. Clapp, J. R., and R. R. Robinson. Osmolality of distal tubular fluid in the dog. J. clin. Invest. 1966, 45, 1847. 
4. Burg, M. B., S. Papper, and J. D. Rosenbaum. Factors influencing the diuretic response to ingested water. J. Lab. clin. Med. 1961, 57, 533.

5. Van Giesen, G., M. Reese, F. Kiil, F. C. Rector, Jr., and D. W. Seldin. The characteristics of renal hypoperfusion in dogs with acute and chronic reductions in glomerular filtration rate as disclosed by the pattern of water and solute excretion after hypotonic saline infusions. J. clin. Invest. 1964, 43, 416.

6. Orloff, J., and M. Walser. Water and solute excretion in Pitressin-resistant diabetes insipidus (abstract). Clin. Res. 1956, 4, 136.

7. Buchborn, E., H. Edel, and S. Anastasakis. Zur Endokrinologie des distalen Nephrons. 1. Klinische Differenzierung und Messung der Phasen I, II, und III der Harnkonzentrierung. Klin. Wschr. 1959, 37, 347.

8. Kleeman, C. R., R. Cutler, M. H. Maxwell, L. Bernstein, and J. T. Dowling. Effect of various diuretic agents on maximal sustained water diuresis. J. Lab. clin. Med. 1962, 60, 224.

9. Walser, M., D. G. Davidson, and J. Orloff. The renal clearance of alkali-stable inulin. J. clin. Invest. $1955,34,1520$.

10. Smith, H. W., N. Finkelstein, L. Aliminosa, B. Crawford, and $M$. Graber. The renal clearances of substituted hippuric acid derivatives and other aromatic acids in dogs and man. J. clin. Invest. 1945, 24, 388.

11. Wolf, A. V. Total renal blood flow at any urine flow or extraction fraction (abstract). Amer. J. Physiol. 1941, 133, 496.

12. Pilkington, L. A., R. Binder, J. C. M. De Haas, and R. F. Pitts. Intrarenal distribution of blood flow. Amer. J. Physiol. 1965, 208, 1107.

13. Earley, L. E., and R. M. Friedler. Observations on the mechanism of decreased tubular reabsorption of sodium and water during saline loading. $J$. clin. Invest. 1964, 43, 1928.

14. Dirks, J. H., W. J. Cirksena, and R. W. Berliner. The effect of saline infusion on sodium reabsorption by the proximal tubule of the dog. J. clin. Invest. $1965,44,1160$.

15. Goldsmith, C., F. C. Rector, Jr., and D. W. Seldin. Evidence for a direct effect of serum sodium concentration on sodium reabsorption. J. clin. Invest. 1962, 41, 850.

16. Bricker, N. S., S. Klahr, and R. E. Rieselbach. The functional adaptation of the diseased kidney. $\mathrm{I}$. Glomerular filtration rate. J. clin. Invest. 1964, 43, 1915.

17. Rector, F. C., Jr., G. Van Giesen, F. Kiil, and D. W. Seldin. Influence of expansion of extracellular volume on tubular reabsorption of sodium independent of changes in glomerular filtration rate and aldosterone activity. J. clin. Invest. 1964, 43, 341.

18. Stein, R. M., R. G. Abramson, and M. F. Levitt. Evidence for a "limit" on distal sodium transport induced by hypotonic saline loading (abstract). Clin. Res. 1965, 13, 558.

19. Blythe, W. B., and L. G. Welt. Dissociation between filtered load of sodium and its rate of excretion in the urine. J. clin. Invest. 1963, 42, 1491.

20. Kamm, D. E., and N. G. Levinsky. Inhibition of renal tubular sodium reabsorption by hypernatremia. J. clin. Invest. 1965, 44, 1144.

21. Arndt, J. O. Diuresis induced by water infusion into the carotid loop and its inhibition by small hemorrhage. The competition of volume and osmocontrol. Pflügers Arch. ges. Physiol. 1965, 282, 313.

22. Gottschalk, C. W. Micropuncture studies of tubular function in the mammalian kidney. Physiologist $1961,4,35$. 